Research.

\title{
MARKETING STRATEGY AT RANCABUAYA BEACH USING THE ANALYSIS FACTORS OF EXPANDED MARKETING MIX AND PROMOTION MIX
}

\author{
Teguh Iman Basuki \\ Economic College of Ekuitas, Bandung, Indonesia \\ teguhib@ekuitas.ac.id (T. I. Basuki)
}

Received: November 10, 2018; Accepted: November 25, 2018; Published: December 31, 2018

To cite this article: Teguh Iman Basuki, Marketing Strategy at Ranca Buaya Beach Using The Analysis Factors of Expanded Marketing Mix and Promotion Mix, The Management Journal of BINANIAGA, Vol. 03, No. 02, December 2018, pp. 09 - 22.

\begin{abstract}
West Java is one of the provinces in Indonesia that has strong potential and wisdom, mountains range from the east to the west of the Bogor Peak area, as well as the southern region which has attractive coastal views and panoramas from Pangandaran district to sukabumi district. One of the southern parts of West Java which has the potential of coastal tourism is Garut regency, one of them is the Rancabuaya beach, the potential of Rancabuaya beach tourism is now being developed to attract tourists, located in Purbayani village in Caringin sub-district with an area of 10 hectares while the current area used as a new tourism area of 2 hectares, which is also directly adjacent to the Indian Ocean with the characteristics of having big tide and large rocks and rock cliffs that are quite high, another potential tourism attraction is the presence of a waterfall directly facing the beach. However, Rancabuaya beach is very beautiful, but the level of tourist visits is less than the total visitors to other southern Jabar (west Java) beach attractions, which is Pangandaran beach. Visitors to rancabuaya beach are very crowded only in certain events such as, New year, Eid or other National holiday. This study aims to find out what the right marketing model can be applied at Rancabuaya beach tourism area. The results of this study indicate that the indicators of income mix and promotion mix get a good response from the respondents and have a strong relationship to the factors that are formed.
\end{abstract}

Keywords: Rancabuaya beach, promotion, marketing

\section{INTRODUCTION}

West Java is one of the provinces in Indonesia having the potential and attractive tourism places, having mountains range from East which is Ciremai mountains up to the West surrounding Puncak area in Bogor, despite of that the development of agro tourism in the mountain ranges such as Gunung Mas area, Agropolitan Cianjur, Big forest park, Ir. $\mathrm{H}$. Djuanda Dago has been on going. Nevertheles, it is developing more and more and a lot of local and foreign tourists are visiting this area. Data of the visitors in West Java Province in 2017 taken from the data of Bureau Statistics Center in 2016 indicated total of foreign tourists was 2.673.379 and local tourists was 39.195 .680 which had distributed into 27 districts and cities in West Java, howevef, total of the tourists overall who visited the tourism location in West Java was 43.703.778. It has explained that the interest of either local or foreign tourists in West Java is very good.

Teguh Iman Basuki. Marketing Strategy at Ranca Buaya Beach Using The Analysis Factors of Expanded Marketing Mix and Promotion Mix 
Table 1 below indicated the tourists who visited tourism area in West Java either districts or cities. Bandung is still the most popular place visited by local and foreign tourists which is 6.450 .468 tourists. The Second one is Bogor which is 5.306.257 tourists.

Table 1. Total of the visitors at tourism area in West Java in 2017

\begin{tabular}{|c|l|c|}
\hline NO & \multicolumn{1}{|c|}{ District } & Total \\
\hline 1 & Bandung & 6.450 .468 \\
\hline 2 & KOTA Bogor & 5.306 .257 \\
\hline 3 & Bogor & 5.183 .992 \\
\hline 4 & Karawang & 4.575 .060 \\
\hline 5 & Subang & 4.226 .272 \\
\hline 6 & Sukabumi & 2.081 .964 \\
\hline 7 & Purwakarta & 1.959 .976 \\
\hline 8 & KOTA Depok & 1.872 .085 \\
\hline 9 & KOTA Bandung & 1.863 .561 \\
\hline 10 & Pangandaran & 1.834 .711 \\
\hline 11 & Bandung Barat & 1.567 .684 \\
\hline 12 & KOTA Cirebon & 1.356 .145 \\
\hline 13 & Kuningan & 1.189 .218 \\
\hline 14 & Sumedang & 1.010 .952 \\
\hline 15 & Garut & 676.841 \\
\hline
\end{tabular}

Data processed of West Java Province in 2017

Table 1 indicates that the big five places visited are in the center and north part of West Java Province, however, other potential area is at the south of West Java Province which will be as good as the center and north one if it is managed and marketed properly, its coastline is $398.05 \mathrm{~km}$ length from Sukabumi district to Ciamis district according to the Master Plan of the Development of southern area of West Java in 2006.

One of the most potential places in the south of west java province is Garut, in the long-term development planning (RPJP) for the period of 2005-2025 the district of Garut has been focusing to the development of tourism area which can create a strong economics structure and a reliable sector which is the trigger of economic development, so that it is expected to be able to improve the society economy. Referring to the document of Master Plan of the Development of West Java area in 2006, the distric of Garut has its coastline of $8.40 \mathrm{~km}$ length describing that it has a long beach, range of hills, steep and rough hills. The other potential tourism area is coral-reef, Garut district has coral-reef of $22 \mathrm{~km}$ length and $100-15 \mathrm{~km}$ width which is from Santolo Cilauteureun area up to Sancang nature preserve, and Cikelet has coral-reef of 750 meters length and 50 meters width.

The potential tourism area of Rancabuaya beach has been developed to attract tourists attention, it is located at the village of Purbayani, subdistrict of Caringin which is 10 hectares square, but it is only 2 hectares has been developed as a new tourism area which is directly adjacent to Hindia Ocean with huge tide, big rock, steep high ocean bank. Nevertheless, another potential tourism place is a waterfall facing directly to the beach.

Having had the potential tourism area at the beach of Rancabuaya and in order to introduce it to the tourists, a well-organized marketing should have to be done obviously, one of the technics is service marketing mix which is one of the tools of the marketer to execute a synergistic and continuous marketing getting an effective result. Referring to

Teguh Iman Basuki. Marketing Strategy at Ranca Buaya Beach Using The Analysis Factors of Expanded Marketing Mix and Promotion Mix 
Zethaml and Bitner in Huriyati (2005:48),concept of traditional marketing mix consists of 4P, Product, Price, Place and Promotion, however, to execute the marketing of service product which is intangible one, can not be stored and it is only can be enjoyed when we receive it, so that, it has to add non traditional marketing mix agent which is another $3 \mathrm{P}$, People, Process and Physical Evidence. So that, it can be concluded marketing the product of service, the $3 \mathrm{P}$ of non traditional agents should have to be added to be $7 \mathrm{P}$ which is expected to reach an effective marketing goals. To support the marketing activity applying the traditional marketing mix, it needs marketing combination with an effective promotion because the area of Rancabuaya beach has not yet been well-known by the people due to a rare information causing the tourists have preferred to go to another place. Therefore, in order to support the marketing execution, it has to be combined again with promotion mix. Nevertheless, in order to gain the market, a reliable strategy of the promotion covering all the information about Rancabuaya beach has to be done and has to be accepted by the customer and other potential market.

\section{Aims of the Research}

1. To figure out the big picture of the execution of service marketing mix and promotion mix.

2. To figure out what factors can be the model of proper marketing Rancabuaya Beach.

\section{THEORITICAL REVIEW}

\section{Service Marketing Mix}

Referring to Tjiptono (2006:31) The weaknesses of traditional marketing mix have made the experts to redefine the tradional marketing mix to be more applicable at service sector. The result is $4 \mathrm{P}$ of tradition marketing mix that is expanded and added other agents of People, Process and Physical evidence.

\section{Promotion Mix}

Marketing promotion has the characteristic of communication that is able to provide an interesting information, an intensive characteristic can attract the people buying the product (Shinta, 2011:142). Performing the promotion, a company has to spend quite expensive cost, so that, it needs a good and effective planning to identify how much money the company should have to spend (Septrianti, 2014)

\section{Advertising}

There are many advertising media such as: printed media, electronic media, billboard, poster, banner, folder, catalogue, slide (Suparyanto, 2015 : 177) Referring to Lupiyoadi (2006:120) aims of the advertising; a) informative advertisement, b) persuasive advertisement, c) reminder advertisement, d) consolidated advertisement.

\section{Personal Selling}

Personal selling is personal relationship where all efforts have been done to educate the customers to choose a certain brand or product (Lovelock: 2017:2017).

\section{Marketing Promotion}

Marketing promotion is a communication accompanied by an incentive (Lovelock: 2011:2017). Referring to Lovelock (2011:207) the objective of marketing promotion is to speed up the customer decision or to motivate the customers to use immediately a certain service in a bigger volume everytime they purchase or they will purchase it more often. 


\section{Direct Marketing}

Direct marketing is an interactive marketing applying one or more advertisement media to influence the measurable response and or the transaction occurred at each location (Kotler: 2016). General form of direct marketing is a direct mail, mail order, direct response, direct selling, telemarketing and digital marketing (Sunyoto, 2015:159)

\section{RESEARCH DESIGN}

The potential tourisme area at Rancabuaya beach has been developed recently to attract the tourists' attention, it locates at Purbayani Village, Caringin Subdistrict which is having 10 square hectares, but it is only 2 square hectars which has been utilized as a tourism area, and it is directly adjacent to Hindia Ocean with a very huge tides and many rocks, steep high oceanbank, and another potential tourism area is a waterfall facing directy to the beach.

The potential tourism area at Rancabuaya beach has to be introduced to the people and it needs a well -coordinated marketing, it is service marketing mix. Service marketing mix is the tool for the marketer to market the product synergistically and continuously to achieve an effective marketing. Referring to Zethaml and Bitner in Huriyati (2005:48), concept of traditional marketing mix consisting of 4P, Product, Price, Place and Promotion, however, marketing a service product having the characteristics of intangible, unstorable, enjoyable only when we receive a service, then, it has to be added some variables of non tradiotional marketing mix which is 3P. People, Process and Physical evidence. So that, it can be concluded that marketing a service product such as tourism, it has to add some variables of marketing mix to be 7P and it is expected to be able to reach an effecting marketing goal. In order to support the marketing activity using traditional marketing mix, it has to combine marketing and an effective promotion, because Rancabuaya beach has not yet well-known for the people and the information is still quite a few, it makes the people choose another place to go. In order to gain the market, a competent strategy of the promotion has to be done, so that all the information about Rancabuaya Beach will be accepted by the customers and other potential market.

The potential Rancabuaya beach which is very good has still needed to be developed not only infrastructure requirement, but also the execution of an effective and strategic marketing management so that the people will know more about Rancabuaya beach and they will choose it as the main place to visit. An effective and strategic marketing management will provide accurate information about the tourism area of Rancabuaya beach covering the distance, time consumed, tourism facility, tourism features, availability of transportation vehicles. Nevertheless, it is expected that Rancabuaya beach will be an alternative place to visit and will be more well-known at the south of West Java instead of Pangandaran beach and Santolo beach.

\section{RESEARCH METHOD}

This research is descriptive and verificative research and sampling technics has applied non probably sampling method, in this case the respondent is taken from each one who is in the place and who has visited Rancabuaya beach which is accidental sampling technics. Total of the respondents who accept and want to answer the questionnaires is 52 persons. The operational variable of promotion mix consists of advertisement, marketing promotion, personal selling, direct selling and marketing mix which is expanded by adding people, process and physical evidence.

Teguh Iman Basuki. Marketing Strategy at Ranca Buaya Beach Using The Analysis Factors of Expanded Marketing Mix and Promotion Mix 


\section{RESULT OF THE RESEARCH}

Factors Analysis KMO \& Bartlett's Test

Table 2

KMO \& Bartlett's Tes

KMO and Bartlett's Test

\begin{tabular}{|l|l|r|}
\hline \multicolumn{2}{|l|}{ Kaiser-Meyer-Olkin Measure of Sampling Adequacy. } & .883 \\
\hline \multirow{2}{*}{$\begin{array}{l}\text { Bartlett's Test of } \\
\text { Sphericity }\end{array}$} & Approx. Chi-Square & 295.881 \\
\cline { 2 - 3 } & $\mathrm{df}$ & 21 \\
\cline { 2 - 3 } & Sig. & .000 \\
\hline
\end{tabular}

Output on the table KMO and bartlett's has indicated the value of KMO Measure of Sampling Adequacy of 0.883 , it has indicated the significance value of bigger than 0.5 . But Approx Chi-square of 295,881 with its sig value of 0.0000 indicating that the correlation of the variables is significant to be processed further more.

\section{Anti Image}

Table 3

Anti Image

\begin{tabular}{|c|c|c|c|c|c|c|c|c|}
\hline \multicolumn{9}{|c|}{ Anti-image Matrices } \\
\hline & & $\begin{array}{l}\text { ADVERTI } \\
\text { SING }\end{array}$ & $\begin{array}{l}\text { PROMOT } \\
\text { ION }\end{array}$ & $\begin{array}{l}\text { PUBI } \\
\text { CITY }\end{array}$ & $\begin{array}{l}\text { DIRECT } \\
\text { SALES }\end{array}$ & $\begin{array}{l}\text { PEO } \\
\text { PLE }\end{array}$ & $\begin{array}{c}\text { PROC } \\
\text { ESS }\end{array}$ & $\begin{array}{l}\text { PHYSICAL } \\
\text { EVIDENCE }\end{array}$ \\
\hline \multirow{7}{*}{$\begin{array}{l}\text { Anti-image } \\
\text { Covariance }\end{array}$} & ADVERTISING & .224 & -.051 & -.098 & -.052 & -.060 & .135 & -.035 \\
\hline & PROMOTION & -.051 & .228 & -.055 & -.050 & -.044 & .000 & -.035 \\
\hline & PUBICITY & -.098 & -.055 & .501 & -.021 & -.010 & -.094 & .068 \\
\hline & DIRECT SALES & -.052 & -.050 & -.021 & .369 & -.049 & -.049 & .040 \\
\hline & PEOPLE & -.060 & -.044 & -.010 & -.049 & .118 & -.080 & -.072 \\
\hline & PROCESS & .135 & .000 & -.094 & -.049 & -.080 & .386 & -.082 \\
\hline & $\begin{array}{l}\text { PHYSICAL } \\
\text { EVIDENCE }\end{array}$ & -.035 & -.035 & .068 & .040 & -.072 & -.082 & .247 \\
\hline \multirow{7}{*}{$\begin{array}{l}\text { Anti-image } \\
\text { Correlation }\end{array}$} & ADVERTISING & $840^{\mathrm{a}}$ & -.228 & -.293 & -.182 & -.367 & .458 & -.151 \\
\hline & PROMOTION & -.228 & $.940^{\mathrm{a}}$ & -.164 & -.172 & -.267 & .000 & -.147 \\
\hline & PUBICITY & -.293 & -.164 & $.908^{\mathrm{a}}$ & -.048 & -.040 & -.213 & .193 \\
\hline & DIRECT SALES & -.182 & -.172 & -.048 & $.944^{a}$ & -.233 & -.131 & .132 \\
\hline & PEOPLE & -.367 & -.267 & -.040 & -.233 & $.859 \mathrm{a}$ & -.373 & -.422 \\
\hline & PROCESS & .458 & .000 & -.213 & -.131 & -.373 & $.797^{\mathrm{a}}$ & -.267 \\
\hline & $\begin{array}{l}\text { PHYSICAL } \\
\text { EVIDENCE }\end{array}$ & -.151 & -.147 & 193 & .132 & -.422 & -.267 & $.890^{a}$ \\
\hline
\end{tabular}

Table Anti Image above has indicated that all the variables have a sign of a degree (a) indicating that it is the value of Measure of Sampling Adequacy (MSA) of the variable. Advertising variable (0.840), Promotion (0.940), Publicity (0.908), Direct Sales (0.944), People (0.859), Process (0.797), Physical Evidence (0.892), indicating that the value of MSA for all the variables in this research is more than 0.5 , so that, it means that all the variables can be applied for the next process.

Teguh Iman Basuki. Marketing Strategy at Ranca Buaya Beach Using The Analysis Factors of Expanded Marketing Mix and Promotion Mix 


\section{Communalities}

Table 4

Communalities

\begin{tabular}{|l|r|r|}
\hline \multicolumn{3}{|c|}{ Communalities } \\
\hline & \multicolumn{1}{|c|}{ Initial } & Extraction \\
\hline ADVERTISING & 1.000 & .742 \\
\hline PROMOTION & 1.000 & .828 \\
\hline PUBICITY & 1.000 & .544 \\
\hline DIRECT SALES & 1.000 & .702 \\
\hline PEOPLE & 1.000 & .907 \\
\hline PROCESS & 1.000 & .519 \\
\hline PHYSICAL & 1.000 & .745 \\
EVIDENCE & & \\
\hline Extraction Method: Principal Component \\
Analysis. \\
\hline
\end{tabular}

Table of Communalities above can analyze the total variants which can be described by general factors which is the smaller value of each variable mentioned of the communalities table explaining that the related variable has a weaker correlation with the factors created. The result of analsis has described that the variable of people influencing $(0.907)$ is the variable having the closest correlation with the factor created since its communal value is the biggest one. But the weakest one is variable Process (0.519) as its value is the smallest one. The table above does not have the communal value of below 0.05 , so that it does not need to retest the factors of analysis because all the variables are considered fit.

Total Varians Explained

Table 5

Total Varians Explained

\begin{tabular}{|c|r|r|r|r|r|r|}
\hline \multicolumn{7}{|c|}{ Total Variance Explained } \\
\hline \multirow{2}{*}{ Component } & \multicolumn{7}{|c|}{ Initial Eigenvalues } & \multicolumn{3}{c|}{ Extraction Sums of Squared Loadings } \\
\cline { 2 - 7 } & \multicolumn{1}{|c|}{ Total } & \% of Variance & \multicolumn{1}{c|}{ Cumulative \% } & Total & \% of Variance & Cumulative \% \\
\hline 1 & 4.987 & 71.248 & 71.248 & 4.987 & 71.248 & 71.248 \\
\hline 2 & .701 & 10.018 & 81.266 & & & \\
\hline 3 & .507 & 7.249 & 88.515 & & & \\
\hline 4 & .361 & 5.162 & 93.678 & & & \\
\hline 5 & .191 & 2.722 & 96.400 & & & \\
\hline 6 & .159 & 2.277 & 98.677 & & & \\
\hline 7 & .093 & 1.323 & 100.000 & & & \\
\hline Extraction Method: Principal Component Analysis. & & & \\
\hline
\end{tabular}

Result of analysis of communal variable has indicated 7 variables that can conduct factor analysis, on the table of Total Variants Explained has produced one component based on eigenvalues out of each variable. On the table of Total Varians Explained, it has indicated that one component has an eigenvalues of more than one $(>1)$ and the biggest value of 4.987 which is the main factor considered mostly by the respondent, The table of Total Varians Explained has indicated that the variety of the total of 71.248 and can be concluded that the related factor has represented the variety of the origin variables.

Teguh Iman Basuki. Marketing Strategy at Ranca Buaya Beach Using The Analysis Factors of Expanded Marketing Mix and Promotion Mix 


\section{Component Matrix}

\section{Table 6 Component Matrix}

\begin{tabular}{|l|r|}
\hline \multicolumn{2}{|c|}{ Component Matrix ${ }^{\text {a }}$} \\
\cline { 2 - 2 } & Component \\
\hline ADVERTISING & 1 \\
\hline PROMOTION & .862 \\
\hline PUBICITY & .910 \\
\hline DIRECT SALES & .738 \\
\hline PEOPLE & .838 \\
\hline PROCESS & .953 \\
\hline PHYSICAL & .721 \\
EVIDENCE & .863 \\
\hline Extraction Method: Principal \\
Component Analysis. \\
\hline a. 1 components extracted. \\
\hline
\end{tabular}

Table of Component Matrix has indicated the value of loading factor of each variable supporting the value of correlation of each variable in the factor created and it can determine the related variable to be put in the factor created. The table of component matrix above has only created one factor along with the variables formed it such as, Advertising (0.862), Promotion (0.910), Publicity (0.738), Direct Sales (0.838), People (0.953). Process (0.721), Physicial evidence (0.863).

\section{The interpretation of Factor Analysis Result}

In order to interprete the result of factor analysis very well, it has to classify the factors using a name indicated, there is not any rule to identify the name. Referring to the result analysis of the factor, this research has identified only one group of the factors and it is factor of marketing and promotion.

\section{Marketing and Promotion Factors}

Marketing and Promotion factors are consisting of the variables of advertising, promotion, publicity, direct sales, process, people, physical evidence. Those seven variables are having a strong connection with the creating factor which is Advertising (0.862), Sales Promotion (0.910), Publicity (0.738), Direct Sales (0.838), People (0.953), Process $(0.721)$, Physical Evidence (0.863), so that they could be interpreted as follows:

1. Advertising correlation value of 0.862 has explained that the tourists who visit Rancabuaya beach have been attracted by the promotion activities done by the beach management and it can be said that the tourists have been coming to Rancabuaya beach due to the promotion which is advertisement either in the printed media or social media and cheap price of the ticket as well as the natural view of the beach.

2. Marketing promotion correlation value of 0.910 is categorized strong though it is the second level having connected with the factor created, it has explained that the visitors who come to Rancabuaya beach are expecting that the management will provide the reward for the events and discount price for the visitors who come in a group.

3. Publicity correlation value of 0.738 has explained that the management has organized a lot of social events at Rancabuaya beach and has invited journalists from printed media and television.

4. Direct sales correlation value of 0.838 has explained that the visitors who come to Rancabuaya beach are interested in buying some souvenirs which they can bring

Teguh Iman Basuki. Marketing Strategy at Ranca Buaya Beach Using The Analysis Factors of Expanded Marketing Mix and Promotion Mix 
them home. Having a lot of tourists from other cities who come to Rancabuaya beach indicating that the venue has been becoming better from year to year.

5. People are the indicator having the strongest correlation value of 0.953 explaining that the visitors of Rancabuaya beach are expecting to get professional guides so that they can get complete information of the condition and situation of Rancabuaya beach and they expect to have a neat and friendly guide.

6. Process correlation value of 0.721 has explained that the respondents have been influenced by the way and process of management and guides who serve them.

7. Physical Evidence correlation value of 0.863 has indicated that the visitors have been influenced by the physical evidence at Rancabuaya beach which is having the forbidden warning boards, safety equipment, parking lots and sitting places or rest area provided by the management.

\section{Marketing Model of Tourism place at Rancabuaya beach}

The result of the research at Rancabuaya beach at Garut district has applied the promotion mix and expanded marketing mix as follows:

\section{Promotion Mix}

\section{Advertising}

Referring to the factor analysis result, the variable of advertising has a correlation value of 0.862 which is strong correlation whict can be concluded that:

1. Since the correlation value of 0.862 which is having strong correlation with the factor created it has explained that the tourists who visit the place due to the advertising activity.

2. In order to promote Rancabuaya beach, the management can advertise it thru advertisement on the printed media or local television, however, in order to have cheaper cost the management can advertise it at social media such as facebook, Instagram, Tweeter, Youtube,etc. Nevertheless it would be better if the management has its owned website mentioning the up to date information consists of location map, entering access, price of the ticket, hotel, the distance from the nearest city, cullinairy tourism, agenda of the events or activities refers to local culture or national events.

3. Developing the potential local food at Rancabuaya beach by identifying the food that can be made and marketed massively e.g. coconut that can be consumed directly or produced such as sari kelapa/extracted water of coconut, dodol kelapa/sticky coconut made of the sticky rice, wajit/sticky coconut sweet, etc.

\section{Sales Promotion}

Result of analysis has indicated the variable of sales promotion has the correlation value of 0.910 which is having a strong correlation with the factor created. It can be concluded that:

1. Result of the analysis of salws promotion has indicated the correlation value of 0.910 which is having a strong correlation with dependent variable (factor created) and it has explained that the visitor have been influenced by sales promotion.

2. In order to improve the visit of the tourist at Rancabuaya beach, the management has provided the package of tourism for the group using a bus with a cheaper price of the ticket comparing to the individual ticket.

3. The potential of local events need to be improved such as traditional ceremony, traditional ritual and other local culture which is involving the tourists to do it, and they will get a memorable gift.

\section{Publicity}

Result of analysis of publicity variable has indicated the correlation value of 0.738 which is strong correlation upon the dependent variable. It can be concluded that:

Teguh Iman Basuki. Marketing Strategy at Ranca Buaya Beach Using The Analysis Factors of Expanded Marketing Mix and Promotion Mix 
1. Result of factors analysis has indicated the correlation value with the factor created of 0.738 which is a strong connection and it can be interpreted that the visitors who come to Rancabuaya beach have been influenced by the management of the place that have been organizing social activities at Rancabuaya beach and has invited journalists from printed media and television.

2. The management of Rancabuaya beach has created a lot of interesting events such as local culture, disposing something to the sea(larung), new years celebration, and during holiday seasons for the student it has organized some events related to national celebration or intenational event which is kites festival, etc.

3. Any kind of regional, national or international events has invited journalist from printed media, local and national television to take news reports about it and to announce it to the people.

4. The management of Rancabuaya beach has invited local people to be involved in the developing of the potential Rancabuaya beach by allowing them to sell some foods and beverages or to rent becyles, ATV, etc.

\section{Direct Sales}

Result of analysis of direct sales variable has indicated that it has a correlation value of 0.838 and it is within the category of a strong connection with factor created.

1. Result of analysis has indated a strong correlation of direct sales and the creating factor, it can be interpreted that the visitors have been influenced by local gifts especially for the visitors who come from other city, beautiful view of the beach.

2. Guide is one factor for the visitor to come to Rancabuaya beach, because they can get complete information about the condition and situation of Rancabuaya beach.

3. Tour guides should have a good appearance, uniform, kindness, politeness and good communication which is the requirement of service industry at Rancabuaya beach.

\section{People}

Result of analysis of direct sales variable has indicated that the variable of direct sales has correlation value of 0.953 which is within a strong connection with the factor created, people variable is the highest value. It can be concluded that:

1. With the highest correlation value of 0.953 , it can be interpreted that the visitors have been influenced by the indicator of people variable, e.g. tour guides, beautiful uniform, kindness and easy to provide the information for the visitors.

2. The expection of the visitors who visit Rancabuaya is to get the tour guides who are kind, polite, wearing beautiful uniform, can give a clear information about the situation and condition of Rancabuaya beach.

\section{Process}

Process variable is having the correlation value of 0.721 which is within a strong connection with the factor created so that it can be concluded that the visitors can be influenced by process variable which is the process to get the information, easy ticket purchase, evacuation, safety mentioned on the standard operational procedure.

\section{Physical Evidence}

Result of analysis of Physical evidence variable has had the correlation value of 0.863 which is within the category of strong connection with the factor created, and physical evidence has a strong correlation value. It can be concluded that:

1. Visiting of the tourists has been influenced by the variable of physical evidence which is sufficient and proper parking lot, seating area, comfortable rest area, warning signages and safety equipments.

2. Availability of safety equipments such as life buoy, safety floating belt, bay watch, rescue boats, etc. 
3. Big and eyecatching warning boards have to be put at a dangerous area for the visitors so that the visitors can see it clearly.

The visitors are also expecting that the management can provide a spacious and well-organzed parking lot and parking ticket is not expensive and parking area is not far from the tourism area, as well as proper seating place.

\section{CONCLUSION AND SUGGESTION}

\section{Conclution.}

1. The advertising having the correlation value of 0.862 indicating that Rancabuaya beach visitors are very concerned about the promotion activities done by the management of the beach refers to the promotion activities such as the advertisement on the printed media and social media as well as cheap price of the ticket and the view is relatively origin and natural.

2. Promotion which is marketing promotrion is having the correlation value of 0.910 which is the second level out of the highest one which is included in the category strong, it explains that the visitors are expecting that the management of Rancabuaya beach can give a gift on the certain events, discount price for the visitors in group.

3. Publicity is having the correlation value of 0.738 upon the factor created, it explains that the management has organized social activities at the tourism area at Rancabuaya beach and has invited some journalists from printed media and television.

4. Direct sales is having the correlation value of 0.838 upon the factor created, it explains that the visitors are interested in visiting to Rancabuaya beach as they could buy some souvenirs. Visitors who have come from other city instead of Garut due to the interesting place to visit and it has been becoming better and better from time to time.

5. People is an indicator which is having the strongest correlation with factor created which is 0.953 , it explains that Rancabuaya beach is having a good prospect as it is having professional tour guides so that the visitors can get a proper information about the condition and situation of Rancabuaya beach. Nevertheless the visitors are expecting that the tour guides are kindness, polite, and wearing a neat uniform.

6. Process has the corelation value of 0.721 , it explains that the respondents of this research have been affected by the strategy and the process of the management and tour guides who serve them.

7. Physical Evidence has the correlation value of 0.863 , it explains that the visitors have been affected by the physical evidence at the tourism location at Rancabuaya beach which is having forbidden signages, safety equipment, parking lot and seating place or rest area provided by the management.

\section{Suggestions.}

1. Advertising

a. Promoting the tourism object of Rancabuaya beach by placing the advertisement on the printed media and local television, in order to have a cheaper cost, the management can place the advertisement on Facebook, Instagram, Tweeter, Youtube, etc, and create its own website about the tourism object with an up-todate information about location maps, entering access, price of the ticket, hotel, the distance from the nearest city, culinary tourism, agenda of the events or activities of local culture or other national events organized by the management.

b. Developing the potential characteristic food of Rancabuaya beach by indentifying the food that can be mass-produced and marketed, e.g. coconut plantation at the beach and visitors can enjoy it, coconut products such as coconut extract, sticky cake of coconut (dodol, wajit), etc. 
2. Sales Promotion

a. In order to increase the total of visitors at Rancabuaya beach, it has to provide the policy about package product of Rancabuaya beach tour for the visitors who visit in a group using bus with cheaper ticket.

b. The potential of local events needs to be developed, e,g, traditional ceremony, traditional ritual and other local cultures, and the events will involve the visitors and the souvenir for them

3. Publicity

a. The management of Rancabuaya beach has to make an interesting event that could attract the tourist to come such as local cultur e.g. larung laut(disposing something to the sea), newyears party, and for students' holiday the events should be national or international event such as kites festival, etc.

b. Any kind of the regional, national or international events organized, journalists from printed media, local and national television are invited to cover the news of the activities organized by the management of Rancabuaya beach.

c. Involvement of local people to develop the potential Rancabuaya beach should have to be done by providing them a special location for them to sell food and beverages, to provide the service such as bycicle rental, ATV rental, etc.

4. Direct Sales

a. Available tour guides who can give proper information to the visitors.

b. Tour guides should have been wearing a neat and proper uniform.

5. People

The visitors expectation is to meet a nice, kind, polite tour guides who can give proper information for then.

6. Process

Tourists are expecting to get easily a complete information about Rancabuaya beach about hotel, route of the destination, easy process to get the ticket.

7. Physical Evidence

a. Availability of safety equipment, floating belt, Baywatch, safety boat, etc.

b. For a dangerous place, warning boards have to be installed using eyecatching color and big board so that they could be seen easily.

c. The visitors/tourists want to have the proper parking lot, and reasonable price of parking, parking lot is not far from the tourism area, comfortable seating place and rest area provided by the management.

\section{REFERENCE}

Armstrong, Gery and Philip Kotler. (2001), Marketing Principles, Book 1, $8^{\text {th }}$ Edition) Jakarta: Erlangga

Amir, Taufiq, M., (2011), Concept and Application of Strategic Management, Jakarta : PT. Raja Grafindo Persada

Aiken, L. R. (1997). Psychological Testing and Assesment. Ninth Edition. Boston: Allyn \& Bacon.

Berman, B., Evans, J. R. (2007), Retail Management, USA, Exam Prep.

Cristopher Lovelock, J. W. (2011). Service Marketing:, People, Technology, Strategic Perspective in Indonesia, Jakarta: Penerbit Erlangga.

Foster, B. (2008), Management Ritel, Bandung : Alfabeta

Fruchter, B. 1954. Introduction to Factor Analysis. New Tork : D. Van Nostrand Company, Ltd.

Teguh Iman Basuki. Marketing Strategy at Ranca Buaya Beach Using The Analysis Factors of Expanded Marketing Mix and Promotion Mix 
The Management Journal of BINANIAGA Vol. 03, No. 02, December 2018

PISSN: $2527-4317$

EISSN: $2580-149 x$

Hurriyati, Ratih. 2005. Marketing Mix and Consumers Loyalty, Bandung : Alfabeta

Kotler, P., and Amstrong, G. (2008), Marketing Principles, $12^{\text {th }}$ Edition, Book 1, Jakarta: Erlangga.

Kotler, P., and Keller, Kevin, L. (2009), Marketing Management $13^{\text {th }}$ Edition - Book 1 , Bahasa Indonesia, Jakarta: Indeks.

(2009). Marketing Management, Jakarta. Erlangga.

(2009), Marketing Mangement $13^{\text {th }}$ Edition - Book 2, Jakarta: Indeks. (2012), Marketing Management, $14^{\text {th }}$ Edition, Harlow: Pearson Education.

Kerlinger, F. N. (1990). Principles of Behavioral Research, Yogyakarta: Gadjah Mada University Press.

Malhotra, Naresh K., (2005), Marketing Research, $4^{\text {th }}$ Edition, PT. Indeks.

Levy, Weitz. (2007). Retailing Management, $6^{\text {th }}$ Edition. New York : Mc.Graw Hill, Irwin

Ma'ruf, H. (2006), Retail Marketing, Jakarta : PT. Gramedia Pustaka Utama.

Peter, P., and Olson, C. (2008), Consumen Behavior and Marketing Strategy, $7^{\text {th }}$ Edition, New York : Mc.Graw Hill, Irwin.

Panter, A. T., Swygert, K. A.. Danistrom, W. G., Tanaka. (1997). Factor Analytic Approaches to Personality Item-Level Data. Journal of Personality Assesment. Vol 68 (3), 561-589.

Schiffman, L., and Kanuk, L. (2008), Consumer Behaviour $7^{\text {th }}$ Edition. Jakarta : PT. Indeks.

Shinta, A. (2011). Marketing Management. Malang: Tim UB-Press.

Stanton, William J. (2005). Marketing Principles, $7^{\text {th }}$ Edition, Jakarta: Elangga.

Sugiyono. (2011), Statistics for The Research, Bandung, Alfabeta.

(2012), Statistics for The Research, Bandung: Alfabeta.

(2012), Business Research Method, $16^{\text {th }}$ Edition, Bandung: Alfabeta.

Simamora, B. (2002), Research Guideline of Consumer Behaviour, Jakarta: PT Gramedia Pustaka Utama.

Suharno. (2010), Marketing in Practice. Edisi Pertama. Yogyakarta : Graha IImu

Suparyanto, R. W. (2015). Marketing Management, Bogor: In Media.

Tjiptono, F. (2008), Strategic Marketing, Yogyakarta, CV Andi Offest. (2009), Marketing Sales. Yogyakarta : Andi.

Utami, W. C., (2010), Management Ritel, Jakarta : Salemba Empat.

Teguh Iman Basuki. Marketing Strategy at Ranca Buaya Beach Using The Analysis Factors of Expanded Marketing Mix and Promotion Mix 
https://media.neliti.com/media/publications/183401-ID-volume-lalu-lintas-ruas-jalanpangalenga.pdf

http://fajar-ferdian.blogspot.co.id/2012/11/sekilas-profil-laut-jawa-barat.html > sekilas profil jawa barat

https://bappeda.jabarprov.go.id/jabar-targetkan-463-juta-wisatawan-pada-2017/

https://id.wikipedia.org/wiki/Pantai_Rancabuaya

http://elib.unikom.ac.id/files/disk1/335/jbptunikompp-gdl-arieftribu-16710-1-perancan-t.pdf

http://download. portalgaruda.org/article. php?article=285525\&val=6468\&title=PENGARUH \%20BAURAN\%20PEMASARAN\%20JASA\%20TERHADAP\%20KEPUTUSAN\%20PEMB ELIAN\%20(Survei\%20pada\%20Pelanggan\%20yang\%20Menggunakan\%20Jasa\%20Pen giriman\%20di\%20Kantor\%20Pos\%20Besar\%20Kota\%20Malang

Teguh Iman Basuki. Marketing Strategy at Ranca Buaya Beach Using The Analysis Factors of Expanded Marketing Mix and Promotion Mix 
The Management Journal of BINANIAGA Vol. 03, No. 02, December 2018 PISSN: $2527-4317$

EISSN: $2580-149 x$

This page intentionally be emptied.

Teguh Iman Basuki. Marketing Strategy at Ranca Buaya Beach Using The Analysis Factors of Expanded Marketing Mix and Promotion Mix 